\title{
Effect of Organisational Change on Performance in Kenyan Chartered Universities: A Sector Comparison
}

\author{
Rael S. Chepkurgat \\ Department of Business Administration, Egerton University, \\ P.O. Box 536-20115 Egerton, Kenya \\ Dinah J. Kipkebut \\ Department of Business Administration, Egerton University, \\ P.O. Box 536-20115 Egerton, Kenya \\ Daniel O. Auka \\ Department of Business Administration, Egerton University, \\ P.O. Box 536-20115 Egerton, Kenya
}

\begin{abstract}
There are varying levels of performance in Kenya Universities as indicated in their rankings despite all of them deploying various strategic positions. Organizational change, despite its popular impact across various industries is yet to be linked with the performance of Kenyan universities. This is a gap that prompted commencement of this study on establishing the effect of organizational change on organizational performance in Kenyan chartered universities among the 48 chartered universities as at September 2017. The objectives of this study were compare organizational change and performance in public and private universities and to determine the effect of organizational change on the performance of Kenyan universities. The study used purposive sampling procedure to select 43 public and private chartered universities in Kenya. Questionnaires were administered to 43 vice chancellors and 103 deputy vice chancellors of the selected universities. A pilot study was carried out from three (3) public and two (2) private chartered universities that did not take part in the study. Pilot testing was done to determine the validity of the instrument while Cronbach internal consistency was used to determine reliability of the instrument respectively. The study used descriptive research design t-test, Pearson correlation and multiple regression analysis. In aggregate terms, the results revealed that organizational change has a significant, positive influence on the performance of the universities. Private universities in Kenya have a stronger strategic orientation and better technologies than public universities. However, public universities have better organisational communication than the private universities. Further regression on the individual aspects of organizational change revealed that strategic orientation, an aspect of organizational change, was the most important change tool to facilitate the organizational performance of the Kenyan universities. Thus it is imperative for universities to tailor their strategic orientation to the needs of the market to stand a chance of not only survival but proper performance. Keywords: Organisation, Organisational change, organisational performance
\end{abstract}

DOI: $10.7176 / \mathrm{EJBM} / 11-18-09$

Publication date:June $30^{\text {th }} 2019$

\subsection{INTRODUCTION}

Universities still remain the centre of knowledge and innovations generation. The university operation globally faces a dynamic and complex environment which calls for radical changes in the university management to adapt and stay afloat (Mwangi \& Waithaka, 2018). University performance which refers to the degree of achievement of the mission at work place or school remains at risk with the constant global changes (Cascio, 2006). Most organizations view their performance in terms of effectiveness in achieving their mission, purpose or goals and efficiency in deploying resources. According to Sifuna (2014), firm's performance is the measure of standard or prescribed indicators of effectiveness, efficiency and environmental responsibility such as cycle time, productivity, waste reduction, and regulatory compliance (Sifuna, 2014). Performance also refers to the metrics relating to how a particular request is handled or the act performing: of doing something successfully, using knowledge as distinguished from merely possessing it. Many academics and practitioners argue that the performance of an organization is dependent on the degree to which the values of the culture are widely shared (Mwangi \& Waithaka, 2018). According to Halkos (2012) organizational change is one of the key factors that influence organizational performance. A Competitive strategy that consist of all approaches that a firm is taking to attract buyers, withstand competitive pressure and improve its market position need to be employed with constant reviews to capture the emerging market needs. The strategies adopted are expected to relate to performance of the company. Grant (2002) reported that long term strategy should be derived from a firm's attempt to seek and sustain an operation on a growth trajectory. Thus, organisations which do not constantly transform their operations to be in tandem with market needs risk collapse or becoming obsolete. Universities are not unique to these problems and are required 
to adopt changes in their strategic positioning in order to survive. With regard to the performance of Kenyan universities, there is limited literature which accurately links important organizational change to the performance indices of the public and private chartered universities in Kenya. This study is therefore filling the gap by empirically determining the efficacy of organizational change in terms of its contribution to the performance of the institutions of higher learning Kenya. The paper reviews existing literature and giving the underlying theory behind the application of organizational changes relative to organizational performance. The paper presents the empirical analysis, discussions and policy recommendations.

\subsection{STATEMENT OF THE PROBLEM}

Kenyan universities just like other universities exist in a competitive and constantly changing market conditions. To sustained performance, they must exchange large parts of their old traditions for untried paths into the future (Okenda, Thuo, \& Kithinji, 2017). Most of the changes adopted by universities include their strategic orientation, technology, people behaviour and organisational communication. The adoption of new strategies varies from one university to another and may influence their actual performance. But the puzzle in Kenya is with regard to the reasons for the actual variation in the university ranking whereby some universities still rank low while others are ranked high. Despite the evidence of the initiation of organisational changes, there is limited information on its effect on the performance of universities. The main aim of this paper therefore is to investigate the effebuild an $t$ of change on university performance and whether there are any differences in change management and performance in public and private universities.

\subsection{LITERATURE REVIEW \\ 3.1 Organizational Change}

Organizational change is a process in which most desirable and suitable future form of an organization is perceived and the route map is decided to achieve the change (Ali et al., 2013). According to Gesell (2010) visionary leadership with innovative approach is key to make this change happen successfully. Higher education the world over is undergoing rapid transformation in the face of changing environmental dynamics (Mathooko, 2013). The author further noted that in Kenya, this transformation has seen a rapid expansion of institutions of higher learning in the recent past making higher education the biggest growth area. According to Boston (2000), institutions of higher learning experience different forces such as competition intensity that influence them for change and these forces will create expectations of improved efficiency and better services. When organizational changes are well planned and carried in a strategic way, it leads to continuous improvement through organizational innovation (Boston, 2000). Institutions of higher learning must transform themselves first if they need to transform society for a more sustainable future. For these institutions to survive in such an environment, their strategies particularly in leadership therefore, need to focus on their customers (students, parents and industry) to deal with emerging environmental challenges which in turn pose managerial challenges. Gesell (2010) argues that the leader's role is very important in formulation, implementation and evaluation of change because it requires a well-structured way of managing the behaviour and attitudes of people working together. It also requires strong commitment of all the people to work together for a stated common vision.

The first measure of change is structure. Ibrahim, Alawaye \& Abosede (2012) defined structure as the way jobs are divided, where decisions are made and how work roles are coordinated. Kong'a (2014) in his study on the effect of organizational change on performance of the Kenyan Judiciary adopted structure and technology as measures of organizational change. Schein (2004) proposed people behaviour and strategic orientation as measures of organizational change. According to Cohen \& Bailey (2007) organizational structure is a valuable tool in achieving coordination of activities as it specifies reporting relationships (who reports to whom), delineates formal communication channels and describes how separate actions of individuals are linked together. The majority of organizational changes can be considered structural changes according to Balogun (2004). Some examples of these types of changes include the implementation of a company-wide non-smoking policy and any changes to the institutions hierarchy of authority and administrative procedures. Structural changes can also be considered transformational changes. Newell (2009) noted that organizational structures can inhibit or promote performance, depending on how effectively the supervisory relationships and workflow influences productivity. He further noted that organizations structures are indicative of how an organization functions and are managed, how information flows and is processed within an organization and how flexible or responsive the organization is. Therefore, a manager needs to know the type of organization she or he is working with in order to derive vital clues about the need or potential for change.

Strategic orientation is the second measure adopted by the study. An organizational strategy is the sum of the actions a company intends to take to achieve long-term goals (Nichols, 2016). These actions make up a company's strategic plan. Strategic plans take at least a year to complete, requiring involvement from all company levels. Top management creates the larger organizational strategy, while middle and lower management adopt goals and plans to fulfil the overall strategy step by step. Developing an organizational strategy for an organization involves first 
comparing its present state to its targeted state to define differences, and then stating what is required for the desired changes to take place. According to Xu \& Clarke (2003), it is only those firms that have put in place appropriate response strategies that will survive and achieve sustainable competitive advantage in institutions of higher learning.

The third measure of organizational change is technology (Duan \& Wei, 2005). Technology includes the use of scientific knowledge such as information and communication technologies (ICT) for practical purposes. It is an essential tool to enable institutions of higher learning to move towards participation in providing knowledge to the society. It also facilitates better mechanisms for administration (production process), alternative strategies for improving teaching and learning, tools for research and dissemination, communication and network building (technology being used). In the last two decades, there has been a widespread use of ICT around the world due to the expected benefits that have been achieved by the governments and organizations that have embraced it (Larsen, 2003). He further noted that technological change has had both positive and negative effects on employment levels. It has increased employment through the creation of new distribution outlets, which also require new original or modified content, resulting in increased employment in both production and distribution of content. On the other hand, it has resulted in displacement of employees, particularly through automation and use of smaller and simplified equipment.

People behaviour is the fourth measure of organizational change. Schein (2004) emphasized that people behaviour and attitude which are major indicators of organizational change normally stay stable until leaders act to change them. To change behaviour, it is important for leaders to demonstrate and provide new values to the employees. Schein (2004) further indicated that negative and positive reinforcement can be used to instil desired values to the employees. Robbins et al. (2009) point out that for managers to motivate employees, they should be sensitive and understand individual differences, and what is important to each employee. This allows managers to individualize goals, level of involvement and rewards to align with individual needs and to design jobs to align with individual needs to maximize motivation potential in jobs. According to Noer (1997), the leader is the most important tool for change since the leader's spirit, insight, wisdom, compassion, values and learning skills are all important facets in the ability to lead others to embrace change. Higgs \& Rowland (2005) reports that leaders' behaviour makes change situations more effective. In addition, leaders must understand the reasons for the failure of change in any organization. They have to develop capabilities to be a successful change agent (Manikandan, 2010). If universities are to survive and keep pace with the rising importance of higher education to economic viability, their leaders must be willing to overcome the human desire to maintain a sense of equilibrium.

The fifth dimension is communication. According to Baker (2002), effective organizational communication focuses on openness in communication between senior management and employees resulting in improved employee engagement and productivity. Also in a cross-cultural environment, building and maintaining rapport for business relationships depends on the effective use of language and understanding different communication styles. Van Reil \& Fombrun (2007) state that communication is at the heart of organizational performance and encompasses organizational initiatives that demonstrate social responsibility and good citizenship. They further indicated that effective organizational communication contributes directly to learning, team work, safety, innovation and quality decision-making in organizations and has become a strategic tool for employee engagement, satisfaction and retention in this age of increased competition for talent.

\subsection{Theoretical review}

\subsubsection{Three-Step Change Theory}

Kurt Lewin (1951) developed a three-step change model by introducing the concept of force field analysis, which examines the driving and resisting forces in any change situation. The positive, driving forces which facilitate change push employees in the desired direction to accept the change plans. On the other hand, negative, constraining forces may hinder change plans as these factors might push employees in the opposite direction resulting in the failure of the change plans. Therefore, these forces must be analyzed and Lewin's three-step model can help shift the balance in the direction of the planned change according to the strategic plan of the organisation (Okenda, Thuo, \& Kithinji, 2017). The first step of Lewin's model of change begins with unfreezing the existing situation or status quo. Unfreezing is necessary to overcome the strains of individual resistance and group conformity. Unfreezing can be achieved by the use of three methods. First, increase the driving forces that direct behaviour away from the existing situation or status quo. Second, decrease the restraining forces that negatively affect the movement from the existing equilibrium. Third, find a combination of the two methods listed above. Some activities that can assist in the unfreezing step include: motivate participants by preparing them for change, build trust and recognition for the need to change, and actively participate in recognizing problems and brainstorming solutions within a group.

In the second step, Lewin posits that the process of changing behaviour is a movement (Hobman, \& Walker, 2015). It is thus necessary to cause a disturbance and move the target system to a new level of equilibrium. In this step three actions are also necessary to assist in instituting the movement: persuading employees to agree that the 
status quo is not beneficial to them and encouraging them to view the problem from a fresh perspective, work together on a quest for new, relevant information, and connect the views of the group to well-respected, powerful leaders that also support the change.

In the final and the third step of Lewin's three-step change model is refreezing. In this step, Lewin recognizes that once change has been implemented for it to be sustained or stick over time, refreezing is important. It is highly likely that the change will be short lived and the employees will revert to their old equilibrium (behaviours) if this step is not taken. It is the actual integration of the new values into the community values and traditions. The crucial action to be taken for the change to be sustained, Lwein states that the third step requires institutionalizing the change through formal and informal mechanisms including policies and procedures (Franck, Roes, De Schepper \& Timmermans, 2018). Thus, sustained change will occur when the combined strength of forward force is greater than the combined strength of the opposing set of forces (Okenda, Thuo, \&Kithinji, 2017).

\subsection{Organizational Performance}

The input output model was used to illustrate the performance of the Organizational performance which was defined as a set of financial and nonfinancial indicators which offer information on the degree of achievement of objectives and results (Griffins, 2006). Organizational performance in this study implied the input, process, output and outcome measures in a university (Ruben, 1999). The performance in institutions of higher learning was illustrated by Ruben (1999) where the author used the input-process-output-outcome model to conceptualize the indicators of performance as follows:

$\stackrel{\text { INPUT }}{\longrightarrow} \stackrel{\text { PROCESS }}{\longrightarrow} \stackrel{\text { OUTPUT }}{\longrightarrow} \stackrel{\text { OUTCOME }}{\longrightarrow}$

Figure 1: The input-process-output-outcome model

The arrows indicate the general direction of equation from input, process, and output until outcomes. The four aspects are what performance measures in universities entail. The Inputs: Inputs can include money, technical expertise, relationships and personnel. Activities: include hiring staff, purchasing equipment and providing other forms of technical assistance. Outputs: the tangible and intangible products that result from project activities. Outcomes: are the benefits that a project or intervention is designed to deliver. Tendency toward performance measurement reflects increasing call for accountability in higher education (Ruben, 1999). This approach was applied in this paper where the tendency toward performance measurement reflects increasing call for accountability in higher education. Performance indicators were recognized as student enrolment, development index and student graduation rates (Kipchumba, 2015).

Table 1: Performance indicators in institutions of higher learning

\begin{tabular}{|l|l|}
\hline Input & $\begin{array}{l}\text { Number of enrolment of students, Number of degree programmes, Number of Professors, } \\
\text { Expenditure on staff development, Annual amount of investment in infrastructure }\end{array}$ \\
\hline Process & Number of student retention, Number of student drop outs, Study efficiency \\
\hline Output & Number of publications in refereed journals, Number of doctorate degrees conferred \\
\hline Outcomes & Number of students graduating, Employment rate of the graduates in graduate job \\
\hline
\end{tabular}

Source: Performance indicators by Ruben (1999)

\subsection{Organizational Change and Organizational Performance}

Organizational change has been noted to have contextual elements of change that influence employee behaviours. According to Kim (2012) change frequency reflects a continuous incremental change in an organization's activities and functions. Ideally, when a change initiative is implemented, employees modify their old work routines to retain more efficient and socially beneficial approaches in the workflow. However, continuous change can also disrupt attempted modifications, resulting in increased employee apprehension about work procedures and social norms.

Griffin (2006) provided evidence that employees experienced higher uncertainty as the number of internal changes (ranks of top management, consolidation of human resource functions) increased a fact that affected their level of performance. Higher change frequencies can also make relationships difficult to maintain, raising doubts about the interpersonal support employees might have previously experienced (Shaw, Ashcroft and Petchey, 2006). Such doubts are likely greater in work teams consisting of members with interdependent work relations. As members' work routines typically involve social interactions, high change frequency could disrupt their previously shared work responsibilities, as well as negatively affect their performance. This clearly shows that change is an important aspect to be considered in any leadership performance related studies because it has an effect on how the two variables relate eventually.

When change is infrequent in a work unit, its operational system remains relatively stable. In such environments, employees' work routines are not interrupted frequently, and adaptation demands are less imposing. As such, members are more confident in performing their tasks, and their need for managers' guidance and support tend to be less salient. When change is frequent, however, work routines that were a source of comfort to employees 
no longer exist (Espedal, 2006). Consequently, Kamugisha (2013) gives a contrary opinion that the need for organizational change starts when organizational management feels dissatisfaction from the current situation and that there should be frequent organizational changes to be able to cope with the ever turbulent environment in which Universities operate. Both change contexts place greater demands on members in the form of new constraints, conflicts, and effort expenditures. The result can lead to disparities between employees' performance, adaptation capabilities, heightening the need for clear guidance and support to cope with continuing change. When work routines and processes undergo changes, it is constructive for managers to engage in quality relational behaviors, such as increasing personal interactions with employees, providing resources and information support for work adjustments, and delivering formal and informal rewards for successful adaptations (Weick \& Quinn, 1999). From the studies, it is evident that change is inevitable justifying the purpose of this study which seeks to establish the mediation by organizational change in the relationship between strategic leadership and organizational performance in Kenyan universities.

The study by Min (2012) established that organizational managers should be transformational during continuous incremental organizational change. Perhaps because of the closer contact managers have with employees in such change contexts, transformational leadership acts to generate beneficial relationships with their employees, which encourage positive change outcomes among the employees and the organization as a whole. The study also established that a frequent change context generates more demand for quality relationships between leaders and employees, which if met result in higher performance levels. It is on this background that this paper seeks to establish the effect of organisational change on performance of the Kenyan universities.

From the above reviewed literature, the following research hypotheses were proposed:

$\mathrm{H}_{\mathrm{O} 1}$ : There are no significant differences in organisational change and organisational performance in public and private universities in Kenya.

$\mathrm{H}_{\mathrm{O} 2}$ : Organisational change does not have a significant relationship with organisational performance

$\mathrm{H}_{\mathrm{O} 3}$ : Organisational change dimensions (namely, organisational structure, strategic orientation, technology, people behaviour and organisational communication) do not have a significant relationship with organisational performance

$\mathrm{H}_{\mathrm{O} 4}$ : The combined effect of organisational change does not have a significant effect on organisational performance in public and private universities

\subsection{METHODOLOGY}

The study population consisted of 48 chartered universities in Kenya out of which 30 were public and 18 were private chartered universities. The study was carried out from a sample of 43 chartered universities derived using formulae by Yamane (1967), out of which 27 were public and 16 were private universities. The respondents of the study were Vice Chancellors and Deputy Vice Chancellors. From the 43 universities, a total of 146 respondents consisting of 43 Vice Chancellors and 103 Deputy Vice Chancellors were targeted. Questionnaires were distributed to the respondents through a 'drop and pick' method. A total of 124 questionnaires were successfully filled giving a response rate of $84.9 \%$.

\section{Measurement of variables}

After a thorough literature review, a comprehensive survey tool was developed. Questionnaire items on Strategic Leadership was measured on a 5 point Likert Scale where $1=$ Not At All; 2 = To A Small Extent; $3=$ Moderate Extent; 4 = Great Extent; and 5= Very Great Extent while questionnaire items on Organizational Performance was measured on a 5 point Likert Scale where $1=$ Very Much Decreased; $2=$ Decreased; $3=$ Constant; $4=$ Increased; and 5= Very Much Increased. Cronbach reliability coefficients were computed using Social Package for Social Sciences (SPSS) software for each variable and the results showed acceptable reliability for all measures as follows: organisational performance $(\alpha=0.848)$, organisational change $(\alpha=0.848)$ while reliability of key change areas was as follows: organisational structure $(\alpha=0.785)$, strategic orientation $(\alpha=0.847)$, technology $(\alpha=0.897)$, people behaviour $(\alpha=0.759)$ and organisational communication $(\alpha=0.858)$.

\subsection{RESULTS AND DISCUSSIONS}

Hypotheses testing involved statistical analysis as shown below in the foregoing sections. Independent samples ttests was carried out to test Hypothesis One. Hypothesis Two and Three were tested using Pearson Correlation analysis while multiple regression analysis was carried out to test Hypothesis Four.

\section{i. Results of Independent samples t-tests}

Ho1: There are no significant differences in organisational change and organisational performance in public and private universities in Kenya. 
Table 1: Results of Independent Samples t-test exploring differences in organisational change and organisational performance based on university sector

\begin{tabular}{|c|c|c|c|c|c|c|}
\hline Variables & University sector & $\mathbf{N}$ & Mean & $\begin{array}{l}\text { Std. } \\
\text { Deviation }\end{array}$ & $t$-Value & Sig. \\
\hline Structure & $\begin{array}{l}\text { Public university } \\
\text { Private university }\end{array}$ & $\begin{array}{l}80 \\
44\end{array}$ & $\begin{array}{l}28.01 \\
28.91\end{array}$ & $\begin{array}{l}3.56 \\
3.20\end{array}$ & -1.389 & .167 \\
\hline Strategic Orientation & $\begin{array}{l}\text { Public university } \\
\text { Private university }\end{array}$ & $\begin{array}{l}80 \\
43 \\
\end{array}$ & $\begin{array}{l}15.64 \\
16.67 \\
\end{array}$ & $\begin{array}{l}3.06 \\
2.49 \\
\end{array}$ & -1.909 & .045 \\
\hline Technology & $\begin{array}{l}\text { Public university } \\
\text { Private university }\end{array}$ & $\begin{array}{l}80 \\
43\end{array}$ & $\begin{array}{l}24.61 \\
26.28\end{array}$ & $\begin{array}{l}3.80 \\
3.23\end{array}$ & -2.438 & .016 \\
\hline People Behaviour & $\begin{array}{l}\text { Public university } \\
\text { Private university }\end{array}$ & $\begin{array}{l}80 \\
44\end{array}$ & $\begin{array}{l}16.46 \\
17.00\end{array}$ & $\begin{array}{l}2.37 \\
2.21\end{array}$ & -1.239 & .218 \\
\hline $\begin{array}{l}\text { Organisational } \\
\text { Communication }\end{array}$ & $\begin{array}{l}\text { Public university } \\
\text { Private university }\end{array}$ & $\begin{array}{l}80 \\
44\end{array}$ & $\begin{array}{l}16.26 \\
17.07\end{array}$ & $\begin{array}{l}2.44 \\
1.87\end{array}$ & -1.904 & .042 \\
\hline Organisational Performance & $\begin{array}{l}\text { Public university } \\
\text { Private university }\end{array}$ & $\begin{array}{l}80 \\
44\end{array}$ & $\begin{array}{l}79.06 \\
79.80\end{array}$ & $\begin{array}{l}9.57 \\
9.72\end{array}$ & -.406 & .686 \\
\hline
\end{tabular}

The results above indicate that the mean scores of structure, people behaviour and organisational performance did not differ significantly in public and private universities $(\mathrm{p}>0.05)$. On the other hand, the mean scores for strategic orientation, technology, and organisational communication were significantly higher in private universities than in public universities $(\mathrm{p}<0.05)$. This suggests that unlike public universities, private universities had strong strategic orientation, adopted technological changes and had better communication processes.

\section{ii. $\quad$ Results of Pearson Correlation analysis}

Pearson Correlation analysis was used to test Hypothesis Two which sought to determine the relationships between organisational change and organisational performance in public and private universities in Kenya.

Ho2: Organisational change does not have a significant relationship with organisational performance The result for Pearson correlation between organisational change and organisational performance are presented in Table 2 below.

Table 2: Pearson Correlation Analysis exploring the relationship between organisational change and organizational performance

\begin{tabular}{l|l|l}
\hline & Organisational Change & Organisational Performance \\
\hline Organisational Change & 1 & $.549^{* *}$ \\
\hline Organisational Performance & $.549^{* *}$ & 1 \\
\hline
\end{tabular}

**. Correlation is significant at the 0.01 level (2-tailed).

The results in Table 2 show that there was a moderate, positive correlation between organisational performance and organisational change $(r=0.549, \mathrm{p}<0.01)$. This implies that organizational performance in Kenyan universities improves when change is managed well.

Ho3: Organisational change dimensions (namely, organisational structure, strategic orientation, technology, people behaviour and organisational communication) do not have a significant relationship with organisational performance

Table 3: Pearson Correlation analysis exploring the relationship between strategic leadership styles and organisational performance

\begin{tabular}{|l|l|l|l|l|l|l|}
\hline & Structure & $\begin{array}{l}\text { Strategic } \\
\text { Orientation }\end{array}$ & Technology & $\begin{array}{l}\text { People } \\
\text { Behaviour }\end{array}$ & $\begin{array}{l}\text { Organisational } \\
\text { Communication }\end{array}$ & $\begin{array}{l}\text { Organisational } \\
\text { Performance }\end{array}$ \\
\hline Structure & 1 & $.599^{* *}$ & $.589^{* *}$ & $.587^{* *}$ & $.620^{* *}$ & $.421^{* *}$ \\
\hline $\begin{array}{l}\text { Strategic } \\
\text { Orientation }\end{array}$ & $.599^{* *}$ & 1 & $.657^{* *}$ & $.575^{* *}$ & $.659^{* *}$ & $.600^{* *}$ \\
\hline Technology & $.589^{* *}$ & $.657^{* *}$ & 1 & $.694^{* *}$ & $.633^{* *}$ & $.510^{* *}$ \\
\hline $\begin{array}{l}\text { People } \\
\text { Behaviour }\end{array}$ & $.587^{* *}$ & $.575^{* *}$ & $.694^{* *}$ & 1 & $.720^{* *}$ & $.412^{* *}$ \\
\hline $\begin{array}{l}\text { Organisational } \\
\text { Communication }\end{array}$ & $.620^{* *}$ & $.659^{* *}$ & $.633^{* *}$ & $.720^{* *}$ & 1 & $.409^{* *}$ \\
\hline $\begin{array}{l}\text { Organisational } \\
\text { Performance }\end{array}$ & $.421^{* *}$ & $.600^{* *}$ & $.510^{* *}$ & $.412^{* *}$ & $.409^{* *}$ & 1 \\
\hline
\end{tabular}

**. Correlation is significant at the 0.01 level (2-tailed).

The results in Table 3 show that organisational change dimensions had significant, positive relationships with organisational performance in the Kenyan universities. Specifically, strategic orientation had the strongest positive correlation with organisational performance $(r=0.600, \mathrm{p}=0.000)$. This implies that top university managers who pay more attention on strategic orientation are likely to achieve better performance for their universities. 
Technology had a significant, positive relationship with organizational performance $(r=0.510, \mathrm{p}=0.000)$. Technological changes were also significant drivers of organizational performance. Organizational structure had a significant positive relationship with organisational performance $(r=0.510, \mathrm{p}=0.000)$. This means that performance increases when the university structure encourages flexibility and decentralisation of authority. People behaviour had a positive significant relationship with organisational performance $(r=0.410, \mathrm{p}=0.000)$ which shows that performance enhances when university top managers value and motivates its employees. Finally, organizational communication had a significant positive correlation with organizational performance $(r=0.409$, $\mathrm{p}=0.000$ ) which means that university performance improves when top management ensures increased flow of information which is important in enhancing efficiency and productivity.

Ho4: Organizational change does not have significant effect on organizational performance in Kenyan universities

The fourth hypothesis of the study was to determine the effect of organizational change on organizational performance of universities which was tested using simple regression analysis. The regression results are presented in Table 4 below.

Table 4: Results of multiple regression analysis establishing the effect of organizational change on organizational performance

\begin{tabular}{|c|c|c|c|c|c|c|c|c|}
\hline \multicolumn{9}{|c|}{ Model Summary } \\
\hline Model & R & \multicolumn{2}{|c|}{ R Square } & Adjusted R Square & \multicolumn{2}{|c|}{$F(\mathrm{ANOVA})$} & \multicolumn{2}{|l|}{ Sig. } \\
\hline 1 & $.549^{\mathrm{a}}$ & .301 & & .295 & \multicolumn{2}{|c|}{51.684} & \multicolumn{2}{|l|}{0.000} \\
\hline \multicolumn{9}{|c|}{ a. Predictors: (Constant), Organizational Change } \\
\hline & & \multicolumn{2}{|c|}{$\begin{array}{l}\text { Unstandardized } \\
\text { Coefficients }\end{array}$} & $\begin{array}{l}\text { Standardized } \\
\text { Coefficients }\end{array}$ & \multirow[b]{2}{*}{$\mathrm{T}$} & \multirow[b]{2}{*}{ Sig. } & \multicolumn{2}{|c|}{$\begin{array}{l}\text { Collinearity } \\
\text { Statistics }\end{array}$} \\
\hline & & $\mathrm{B}$ & Std. Error & Beta & & & Tolerance & VIF \\
\hline \multicolumn{2}{|c|}{ (Constant) } & 35.290 & 6.172 & & 5.718 & .000 & & \\
\hline \multicolumn{2}{|c|}{ Organizational Change } & .429 & .060 & .549 & 7.189 & .000 & 1.000 & 1.000 \\
\hline
\end{tabular}

a. Dependent Variable: Organizational Performance

The results of the model summary indicate that organizational change in Kenyan Universities contributed $30.1 \% \quad$ (R Square $=0.301$ ) of the variance in the performance of Universities. Specifically, organizational change has a significant, positive influence on the performance of the universities $(\beta=0.549, \mathrm{p}=0.000)$. This implies that performance in universities is enhanced when change is initiated effectively.

Further multiple regression analysis was carried out to determine the effect of the individual dimensions of organizational change on organizational performance as shown below in Table 5.

Table 5: Results of multiple regression analysis establishing the effect of dimensions of organizational change on organizational performance

\begin{tabular}{|c|c|c|c|c|c|c|c|}
\hline Model & $\mathrm{R}$ & R Square & $\begin{array}{l}\text { Adjusted } \\
\text { Square }\end{array}$ & \multicolumn{2}{|c|}{$\mathrm{R} F$ (ANOVA) } & \multicolumn{2}{|l|}{ Sig. } \\
\hline 1 & $.621^{\mathrm{a}}$ & .386 & .359 & \multicolumn{2}{|l|}{14.583} & \multicolumn{2}{|l|}{.000} \\
\hline \multicolumn{8}{|c|}{$\begin{array}{l}\text { a. Predictors: (Constant), Organisational Communication, Structure, Technology, Strategic Orientation, People } \\
\text { Behaviour }\end{array}$} \\
\hline & \multicolumn{2}{|c|}{$\begin{array}{l}\text { Unstandardized } \\
\text { Coefficients }\end{array}$} & $\begin{array}{l}\text { Standardized } \\
\text { Coefficients }\end{array}$ & \multirow[b]{2}{*}{$\mathrm{T}$} & \multirow[b]{2}{*}{ Sig. } & \multicolumn{2}{|c|}{ Collinearity Statistics } \\
\hline & B & Std. Error & Beta & & & Tolerance & VIF \\
\hline (Constant) & 43.871 & 6.375 & & 6.881 & .000 & & \\
\hline Structure & .063 & .281 & .022 & .224 & .823 & .528 & 1.895 \\
\hline Strategic Orientation & 1.697 & .356 & .522 & 4.762 & .000 & .440 & 2.274 \\
\hline Technology & .518 & .292 & .199 & 1.772 & .079 & .418 & 2.392 \\
\hline People Behaviour & -.032 & .488 & -.008 & -.066 & .947 & .392 & 2.553 \\
\hline $\begin{array}{l}\text { Organisational } \\
\text { Communication }\end{array}$ & -.363 & .502 & -.087 & -.723 & .471 & .365 & 2.740 \\
\hline
\end{tabular}

\section{Dependent Variable: Organisational Performance}

The results in Table 5 indicate an improvement in the model with an upward shift in the R squared from 0.301 to 0.425 when focus is shifted to the dimensions of organisational change. This implies that individual change drivers explain the variance in performance better than consolidating the factors into one variable. Specifically, the standardised beta coefficients show that strategic orientation $(\beta=0.522, p=0.000)$ was the most important organizational change tool to facilitate the organizational performance of the Kenyan universities.

Further regression analysis to determine whether there are sector differences in the effect of organisational change on organisational performance showed that strategic orientation was the most important predictor of 
organisational performance as indicated in Table 6 .

Table 6: Regression analysis on the effect of dimensions of organizational change on organizational performance in public and private universities

\begin{tabular}{|c|c|c|c|c|c|c|c|c|}
\hline \multicolumn{9}{|c|}{ Model Summary } \\
\hline University sector & Model & $\mathrm{R}$ & R Square & \multicolumn{2}{|c|}{ Adjusted R Square } & \multicolumn{3}{|c|}{$F$ (ANOVA) Sig. } \\
\hline Public university & 1 & $.652^{\mathrm{a}}$ & .425 & \multicolumn{2}{|c|}{.386} & 10.944 & \multicolumn{2}{|l|}{.000} \\
\hline Private university & 1 & $.608^{\mathrm{b}}$ & .370 & \multicolumn{2}{|l|}{.282} & 4.224 & \multicolumn{2}{|l|}{.004} \\
\hline \multicolumn{9}{|c|}{$\begin{array}{l}\text { a. Predictors: (Constant), Organisational Communication, Technology, Structure, Strategic Orientation, People } \\
\text { Behaviour }\end{array}$} \\
\hline \multicolumn{9}{|c|}{$\begin{array}{l}\text { b. Predictors: (Constant), Organisational Communication, Structure, Technology, Strategic Orientation, People } \\
\text { Behaviour }\end{array}$} \\
\hline & & \multicolumn{2}{|c|}{$\begin{array}{l}\text { Unstandardized } \\
\text { Coefficients }\end{array}$} & \multirow{2}{*}{$\begin{array}{l}\text { Standardized } \\
\text { Coefficients } \\
\text { Beta }\end{array}$} & \multirow[b]{2}{*}{$\mathrm{T}$} & \multirow[b]{2}{*}{ Sig. } & \multicolumn{2}{|c|}{$\begin{array}{l}\text { Collinearity } \\
\text { Statistics }\end{array}$} \\
\hline & & B & Std. Error & & & & Tolerance & VIF \\
\hline \multicolumn{9}{|c|}{ Public Universities } \\
\hline (Constant) & & 41.932 & 7.385 & & 5.678 & .000 & & \\
\hline Structure & & .272 & .330 & .101 & .824 & .413 & .515 & 1.941 \\
\hline Strategic Orienta & ion & 1.641 & .407 & .524 & 4.031 & .000 & .460 & 2.176 \\
\hline Technology & & .533 & .327 & .212 & 1.628 & .108 & .459 & 2.178 \\
\hline People Behaviou & & -.239 & .550 & -.059 & -.435 & .665 & .420 & 2.380 \\
\hline $\begin{array}{l}\text { Organisational } \\
\text { Communication }\end{array}$ & & -.327 & .599 & -.083 & -.546 & .586 & .334 & 2.996 \\
\hline \multicolumn{9}{|c|}{ Private Universities } \\
\hline (Constant) & & 49.421 & 14.621 & & 3.380 & .002 & & \\
\hline Structure & & -.734 & .607 & -.230 & -1.210 & .234 & .486 & 2.059 \\
\hline Strategic Oriento & ion & 2.041 & .760 & .548 & 2.688 & .011 & .421 & 2.374 \\
\hline Technology & & .600 & .715 & .192 & .839 & .407 & .334 & 2.992 \\
\hline People Behaviou & & 1.043 & 1.189 & .223 & .877 & .386 & .270 & 3.702 \\
\hline $\begin{array}{l}\text { Organisational } \\
\text { Communication }\end{array}$ & & -.934 & 1.042 & -.183 & -.897 & .376 & .420 & 2.379 \\
\hline
\end{tabular}

a. Dependent Variable: Organisational Performance

\section{Discussions}

The main objective of the study was to determine the effect of organisational change on organizational performance in public and private universities in Kenya. The findings are discussed below:

University sector: The result for university sector indicates that generally, private universities have implemented change more than the public universities. This was indicated by the higher scores of private universities in strategic orientation, technology integration. This indicates that the private universities were doing better generally in terms of strategic orientation, organisational communication and technology use in university operations. This is consistent with study by Jurisch, Ikas, Wolf, \& Krcmar (2013) who compared change management among private and public institutions and found that unlike public institutions, private organizations invested a little more effort in communicating the need for and desirability of change and thus convince their employees of the necessity for change On the other hand, there were no significant differences in the scores of organisational structure, people behaviour and organisational performance. This implies that both private and public universities were at the same level of implementation of organisational structures, people behaviour, and organisational performance.

Private universities had better also improved their communication systems more than the public universities. This was evident in higher scores of organisational communication in private than the public organisations. This is in contrast to the findings of Alford \& Greve (2017) also analyzed who postulated that public participation, consultation, information-sharing and similar artefacts of democratic policies evident in many public organizations made it possible for public institutions to communicate better than private organizations which only communicate selectively.

Organisational change and performance: The analysis showed that organisational change was an important determinant of performance in Kenyan universities. The implication is that universities in Kenya need to incorporate organisational changes to keep pace with the dynamic environment of higher learning. Consistent with this finding Gitonga (2014) found a positive and significant relationship between the organisational change and performance at the Capital Markets Authority in Kenya. Similarly, Atieno (2017) in a study on the effect of strategic change on organizational performance found that implementation of administrative strategic change 
elevates organizational performance.

Organisational structure: The analysis showed that there was no statistically significant differences in the mean scores of organisational structure in public and private universities. Contrary to this study, Razia (2015) in a study on the effect of organizational structure on effectiveness of private and public Universities in Kenya found that there was a slight but significant difference in organizational structure between public and private universities with private having a clear and functioning structure.

Strategic orientation: The results showed that strategic orientation was positive significant driver of organisational performance. Consistent with this study finding, Abdallah et al. (2014) found that strategic orientation had a significant positive influence on innovative improvement of organizations and the resultant effect on organizational performance. However, these findings contradict those of Obeitad (2016) who studied telecommunication companies and found that strategic orientation did not affect organizational performance. The author concluded that telecommunication companies in Jordan were not necessarily implementing their proposed strategies in the right way, thereby reducing the full impact that can be received from those strategies on their performance. Hence even though there is a huge possibility of a positive impact, it is important to implement strategies properly.

Further, the results for t-test analysis showed that private universities hada stronger strategic orientation than public universities which implies that private universities have successfully implemented their strategic plans unlike private universities. This result contradicts those of Giuri, Munari, Scandura, Toschi (2018) who reported that public universities have historically benefitted from government funding and tend to grow faster and develop a strong strategic orientation than the private universities. However, they indicated that there are few global leading private universities which are performing better than public universities.

Technology: The results of t-test analysis showed that private universities had more advanced technology that enhanced service delivery and improved data storage and information management as compared to public universities. Contrary to this finding Gudo et al. (2011) reported that technological advancement was one of the opportunities seized by public universities leading to their higher rankings even in the Webometric global rankings released every year. The private universities however are also integrating these technologies even as they grapple with limited funding due to lower student enrolment.

The regression results showed that technology did not significantly performance of universities. This was contrary to studies that found that technology development has resulted in automation of accounting functions, management of information in other administrative units; development of microcomputer technology and a multitude of local applications that have led to improvement in productivity resulting in higher performance (Gagnon \& Dragon, 1998; Hung, 2006). Similarly, Nakola et al. (2015) analysed the performance of SMEs in Kenya and concluded that technological orientation had a positive and significant effect on SME performance. They advised that SMEs should allocate resources for investments in latest technologies and future forecasted technological changes to attain competitive advantage. Additionally, they reported that technology significantly contributed to internal processes due to speed, reliability and information management.

People behaviour: The t-test and regression results for people behaviour indicated that there were no significant differences in people behaviour in private and public universities. Similarly, Mwangi and Waithaka (2018) established the influence of organizational culture (a manifestation of people behavior) on the performance of universities and observed that there was no significant difference in organisational between private and public universities. But Monte (2017) noted that there was huge difference in organisational behaviour between private and public organisation whereby they noted that staff in public sector for instance do not tend to do unpaid labor and are more absent from work.

Organisational communication: The results of the t-test analysis showed that organisational communication was more effective in private universities than in public universities. It could be that the private institutions are open to information dissemination due to their wider quest to reach many prospective customers. And with time they could have invested in the communication systems and built a reputation of better performance more than public universities in Kenya. Contrary to this study, Sataøen \& Wæraas (2016) found that public institutions had more developed communication web-based portals which were the key informational delivery channels through which they disseminated their products to their target markets.

\subsection{CONCLUSIONS AND RECOMMENDATIONS}

The paper finds evidence that organizational change is a crucial driver of organizational performance. The timely and continuous adaptation of institutions of higher learning to the rapid changes that take place in the external environment calls for rapid strategic changes. Thus, organizational change is a major precondition for survival and growth of institutions. It is thus important for the university management to consider implementing organizational change in the organization as it is important driver of organizational performance of the Kenyan universities. The regression results showed that strategic orientation had a strong influence in the performance of both public and private universities. This means that top management in both public and private universities should ensure effective 
formulation and implementation of their strategic plans in order to attain high level of performance. The correlation results also showed that the organisational change factors namely, structure, technology, strategic orientation, people behaviour and organisational communication had positive relationship with organisational performance. Further, the t-test results showed that private universities had better developed strategic plans, technologies and communication systems than public universities.

The paper recommends that with the rapid changing global needs that require university intervention in terms developing the required innovation, universities need to change accordingly to remain relevant. Again the universities need maintain a strong strategic orientation and develop the technologies that ease service delivery by cutting down lengthy bureaucracies. The study also recommends that top management of public universities should invest in information technology and more effective communication systems so as to elevate their performance in the global market.

\subsection{LIMITATIONS OF THE STUDY}

The limitation of this study include: participants' honesty, perception and emotions at the time of filling the questionnaire which arisen from the self-report questionnaire. However, the limitation were suppressed by the researchers by elaborating the questions whenever required. The study also used cross-sectional data which limits its implication on long term effects of strategic leadership styles on university performance. The study thus recommends the use of a longitudinal design to evaluate the evolution of university changes and performance over time.

\section{Areas for further research}

This study contributes to the understanding of the relationship between organizational change and organizational performance in Kenyan chartered universities. However, further research is necessary to address one of the limitations of this study which was that the study was a cross sectional survey meaning research was carried out at a point in time. The study therefore recommends a similar study to be conducted using longitudinal research design to monitor and evaluate the impact of various organizational changes on performance of Kenyan Universities.

\section{Acknowledgement}

I wish to acknowledge assistance from my supervisors for guiding me throughout the study period. I am also indebted to the University for the tuition waiver for my studies.

\subsection{REFERENCES}

1. Abdallah, A., Obeidat, B. and Aqqad, N. (2014). The Impact of Supply Chain Management Practices on Supply Chain Performance in Jordan: The Moderating Effect of Competitive Intensity. International Business Research, 7: 13-27.

2. Alford, J. \& Greve, C. (2017). Strategy in the Public and Private Sectors: Similarities, Differences and Changes. Administrative sciences, 7(35): 1-17.

3. Baker, K.A. (2002). Organizational Communication in Management Benchmarking, US Office of Science, Dept of Energy. Washington D C.

4. Balogun, J., \& Johnson, G. (2004). Organizational restructuring and middle manager sensemaking. The Academy of Management Journal, 47, 523-549.

5. Boston, C. (2000). The social scientific study of leadership: Quo vadis? Journal of Management, 23, 409-473. In Yang, K. S., Hwang, K. K., \& Kim, U. (Eds.), Scientific advances in indigenous psychologies: Empirical, philosophical, and cultural contributions. London: Sage Inc.

6. Cascio, W.F. (2006). Managing Human Resource: Productivity, Quality of work life and profits. Boston: McGraw-Hill/Irwin

7. Cohen, S.G. and Bailey, D.E. (2007). Total Quality Management. People and Teams. Journal of Management. 23(3), 568-590.

8. Duan, J.C., Wei, J., 2005. Executive stock options and incentive effects due to systematic risk. Journal of Banking and Finance 29, 1185-1211.

9. Franck E., Roes L., De Schepper S., Timmermans O. (2018) Team Resource Management and Quality of Care. In: Van Bogaert P., Clarke S. (eds) The Organizational Context of Nursing Practice. Springer, Cham.

10. Gagnon, Y.C. and Dragon, J. (1998). The impact of technology on organizational performance. Optimum, the Journal of Public Sector Management, 28(1): 19-31.

11. Gesell. I, (2010), Leadership and Legislative conference (AIA Grassroots) Agile Leadership: Innovative Approaches to Leading in certain Times, Leadership and Legislative Conference, Washington, D.C.

12. Gitonga, E. M. (2014). The Effects of Strategic Change on Organization Performance. A Case Study of Capital Markets Authority, Kenya. The strategic journal of business and change management, 2(3), 38-51. 
13. Giuri, P., Munari, F., Scandura, A., \& Toschi, L. (2018). The strategic orientation of universities in knowledge transfer activities. Technological Forecasting and Social Change. https://doi.org/10.1016/j.techfore.2018.09.030

14. Grant, R.M. (2002). Contemporary Strategy Analysis, 4th ed., Oxford: Blackwell.

15. Griffins, L. W. (2006). Strategic planning: concept and cases. Strategic Management Journal, 16(2), 71-83.

16. Gudo, C.O., Olel, M.A., Oanda I.O. (2011).University Expansion in Kenya and Issues of Quality Education: Challenges and Opportunities. International Journal of Business and Social Science, 2(20): 203-14.

17. Halkos, George (2012): Importance and influence of organizational changes on companies and their employees. Munich Personal RePEc Archive Paper No. 36811. Retrieved from: https://mpra.ub.unimuenchen.de/36811/1/MPRA paper 36811.pdf

18. Higgs, M and Rowland, D. (2005) All Changes Great and Small: Exploring Approaches to Change and its Leadership. Journal of Change Management, Vol. 5, No. 2, pp 121-151, June 2005.

19. Hobman, E. V., \& Walker, I. (2015). Stasis and change: social psychological insights into social-ecological resilience. Ecology and Society, 20(1). doi:10.5751/es-07260-200139

20. Hung, R.Y. (2006) Business process management as competitive advantage: a review and empirical study, Total Quality Management \& Business Excellence, 17:1, 21-40, DOI: 10.1080/14783360500249836

21. Ibrahim, O. O., Alawaye, J. K. \& Abosede, S.O. (2012). The middle management perspective on strategy process: contributions, synthesis, and future research. Journal of Management, 34(6): 1190-1221.

22. Jurisch, Ikas, Wolf, \& Krcmar. (2013). Key Differences of Private and Public Sector Business Process Change. e-Service Journal, 9(1), 1-27.

23. Kamugisha, S. (2013).The effects of change management in an organization: a case study of National University of Rwanda. A published $\mathrm{PhD}$ thesis.

24. Kim, M.S. (2012). Measuring job related situational strength and assessing its interactive effects with personality. Journal of Management. 45 (5), 234-254.

25. Kipchumba, S. K. (2015). Government Funding and College Outcomes Improvements of Public Universities in Kenya.PhD Thesis, Nanjing Agricultural University, China.

26. Kong'a, B. J. (2014). In the study on the effect of organizational change on performance. A case of the Kenyan Judiciary. A unpublished thesis.

27. Larsen, B. (2003). Courts of the Future; Law and Information Technology. Swedish View: Ananthology produced by the IT Law Observatory of the Swedish ICT Commission, Stockholm, SOU: 112, 225-238.

28. Lewin, K. (1951). Field Theory in Social Science: Selected Theoretical Papers (ed. Cartwright D). New York: Harper \& Row.

29. Machuki, V.N. (2011). The influence of the external environment on the performance of publicly quoted companies in Kenya. University of Nairobi, Kenya.

30. Manikandan S. (2010). Data transformation. Journal of Pharmacology and Pharmacotherapy, 1(1):126-137: http://www.jpharmacol.com/text.asp?2010/1/2/126/72373

31. Mathooko, S. R. (2013). Performance Measurement and Control Systems for Implementing Strategy. Upper Saddle River, NJ: Prentice Hall.

32. Monte, P. A. (2017). Public versus private sector: Do workers' behave differently? EconomiA, 18 (2017): 229-243.

33. Mwangi, R.W. \& Waithaka, P. (2018). Organizational culture and performance of public universities in Kenya. International Academic Journal of Human Resource and Business Administration, 3(2), 288-313.

34. Mwangi, R.W. \& Waithaka, P. (2018). Organisational culture and performance of public universities in Kenya. International Academic Journal of Human Resource and Business Administration, 3(2), 288-313

35. Nakola, J.O., Tarus, B. K., Buigut, K. and Kipchirchir, K.E. (2015). Effect of Strategic Orientation on Performance of Small and Medium Enterprises: Evidence from Kenya. International Journal of Economics, Commerce and Management United Kingdom, 111(11):336-351.

36. Newell, S. (2009).Teams and Teamwork. Business Magazine. London.

37. Okenda, R., Thuo, A. \&Kithinji, M. (2017). Effects of change on organizational performance: A case of the Ministry of Environment, Water and Natural Resources. International Academic Journal of Human Resource and Business Administration, 2(3), 501-520.

38. Razia, M. (2015).A Comparative Analysis of Organizational Structure and Effectiveness between Public and Private Universities: A Case of University Of East Africa-Baraton and Moi University in Kenya. International Journal of Humanities and Social Science Invention, 4(8): 15-25

39. Ruben, B. D., 1999, Toward a Balanced Scorecard for Higher Education: Rethinking the College and University Excellence Indicators Framework, Higher Education Forum, Center for organizational Development and Leadership. Rutgers University.

40. Sataøen, H. L., \&Wæraas, A. (2016). Building a Sector Reputation: The Strategic Communication of National Higher Education. International Journal of Strategic Communication, 10(3), 165-176. 
41. Sifuna, I.N. (2014). Effect of competitive strategies on performance of public universities in Kenya. Unpublished research project submitted to the school of business in partial fulfilment of the requirements of the degree of master of business administration of Kenyatta University. Retrieved from: https://irlibrary.ku.ac.ke/bitstream/handle/123456789/10090/Effect $\% 20$ of\%20competitive\%20strategies\%E2\%80\% A6.pdf? sequence $=1 \&$ isAllowed $=\mathrm{y}$

42. $\mathrm{Xu}, \mathrm{L}$. and Clarke D. (2003).New approaches to effective leadership: cognitive resources and organizational performance. New York, NY: Wiley.

43. Yamane, Taro. (1967). Statistics: An Introductory Analysis, 2nd Edition, New York: Harper and Row. 